Acta Universitatis Nicolai Copernici • Pedagogika XL/2/2020

Nauki Humanistyczno-Społeczne • Zeszyt 452

DOI: http://dx.doi.org/10.12775/AUNC_PED.2020.018

\title{
Ewelina Wesołek
}

Instytut Nauk Pedagogicznych

Uniwersytet Mikołaja Kopernika w Toruniu

https://orcid.org/0000-0002-9230-839X

\section{Przekonania magiczne \\ W MIĘDZYPOKOLENIOWYM PRZEKAZIE \\ DZIEDZICTWA KULTUROWEGO. \\ REFLEKSJA ETNOPEDAGOGICZNA}

\section{Magical Beliefs in the Intergenerational Transmission of Cultural Heritage. Ethnopedagogical Reflection}

\begin{abstract}
Abstrakt
Celem artykułu jest przedstawienie znaczenia przekonań magicznych obecnych w międzypokoleniowym przekazie dziedzictwa kulturowego. Część teoretyczna pracy została oparta na definicji dziedzictwa kulturowego autorstwa Stanisława Ossowskiego. Badania prowadzone były na terenie wschodniej Wielkopolski z wykorzystaniem wywiadów pogłębionych częściowo strukturalizowanych. W badaniu uczestniczyło 6 rodzin, łącznie 21 osób z trzech pokoleń. Zebrany materiał pozwolił na przedstawienie znaczenia dziedzictwa kulturowego i magii w życiu współczesnych pokoleń. Następnie zaprezentowano podejście osób badanych do magii jako elementu dziedzictwa kulturowego, typologię magii i proces dziedziczenia przekonań magicznych.

Słow a kluc z owe: dziedzictwo kulturowe, przekaz wzorów kulturowych, socjalizacja, edukacja, rodzina, praktyki magiczne, wierzenia magiczne
\end{abstract}




\begin{abstract}
The objective of the article is to presents the meaning of magical beliefs in the intergenerational transmission of cultural heritage. The theoretical part of the work was based on Stanisław Ossowski's definition of cultural heritage. The research was conducted with the use of partially structured in-depth interviews. Families, a total of 21 people from three generations, participated in the study. The author highlights the meaning of cultural heritage and magic in the life of modern generations. Next presents attitudes towards magic as a subject of cultural inheritance, typology of magic, features and the process of inheriting attitudes magic.
\end{abstract}

Ke y w o r d s: cultural heritage, transfer of culture patterns, socialization, education, family, magical practice, magical belief

\title{
Wstęp
}

Celem niniejszego tekstu jest przedstawienie przekonań magicznych pojawiających się w międzypokoleniowym przekazie dziedzictwa kulturowego oraz opisanie znaczeń tych przekonań. Definiując dziedzictwo, czerpałam z koncepcji zaproponowanej przez Stanisława Ossowskiego. W dalszej części tekstu, opierając się na wynikach badań własnych, dokonałam typologii przejawów magicznych oraz postaw rozmówców wobec nich. Następnie skupiłam się na dziedzictwie kulturowym, analizując jego elementy na przykładzie szeroko pojętej magii. Opisane elementy pozwalają nam poznać współczesne rozumienie magii oraz rolę, jaką przekonania magiczne pełnią w życiu współczesnych ludzi.

Podjęcie takiego tematu w obszarze pedagogiki może budzić pewne wątpliwości, dlatego pragnę odwołać się do myśli Romana Schulza, który za obszar poznania pedagogicznego uznaje „sprawy ludzkie”, w zakres których niewątpliwie wchodzi podjęty temat. Autor wskazuje na apel o wzbogacenie dyskursu pedagogicznego o perspektywę an-

1 R. Schulz, Pedagogika jako nauka o człowieku - próba dookreślenia idei, w: Pedagogika we wspótczesnym dyskursie humanistycznym, red. T. Lewowicki. Warszawa-Kraków 2004, s. 118. 
tropologiczną. Kategorią centralną antropologii pedagogicznej jest bowiem człowiek, rozumiany jako podmiot rozwoju generalnie, czyli jako podmiot rozwijający się w sensie nie tylko przyrodniczym, osobowym, ale także - co mnie najbardziej interesuje - w sensie kulturowym ${ }^{2}$.

Uzasadnienie podjęcia takiego tematu znajdujemy również w definicji magii. Zagadnienie magii i przekonań magicznych towarzyszy człowiekowi niemal od początku istnienia ludzkości. Bronisław Malinowski wskazuje, że magia nie została wymyślona ani stworzona, ale od początku była dodatkiem do procesów, które interesują człowieka, a których nie potrafił on wyjaśnić3 . Według Anny Mrozek-Dumanowskiej magia połączona jest z egzystencją człowieka, sprawami życia i śmierci, dlatego jest zjawiskiem występującym we wszystkich epokach ludzkości $^{4}$. Uwzględniając perspektywę antropologiczną, uznałam zagadnienie obecności magii w życiu człowieka za temat odpowiedni dla pedagogiki.

\section{Magia jako cecha dziedzictwa kulturowego: uwagi teoretyczne}

Całość koncepcji niniejszej pracy oparłam na propozycji rozumienia dziedzictwa kulturowego autorstwa Stanisława Ossowskiego. Przed przystąpieniem do omówienia koncepcji dziedzictwa należy wyjaśnić sposób, w jaki definiuje się kulturę. Dla przejrzystości teorii z wielu propozycji wybrałam koncepcję kultury Ossowskiego. Według badacza kultura to zespół dyspozycji psychicznych, który jest przekazywany w obszarze danej zbiorowości w drodze kontaktu społecznego ${ }^{5}$. Pojęcie dziedzictwa ma swój rodowód w języku prawniczym, łacińskie patrymonium oznacza majątek rodowy, dziedzictwo, dobra przekazywane dzieciom przez dorosłych. Ossowski zaznacza, że o dziedziczeniu można mówić w kontekście zasobów ekonomicznych oraz dóbr niema-

2 Tamże, s. 116-117.

3 B. Malinowski, Mit, magia, religia, Warszawa 1990, s. 429.

4 A. Mrozek-Dumanowska, Człowiek $w$ labiryncie magii, Warszawa 1990, s. $10-11$.

5 S. Ossowski, Z zagadnień psychologii społecznej. Dzieła, t. 3, Warszawa 1967, s. 163. 
terialnych, np. nazwiska czy wiedzy tajemnej ${ }^{6}$. W interesującym mnie aspekcie pojęcie dziedziczenia będzie się odnosić do sytuacji, w której dochodzi do upodobniania się do kogoś biologicznie lub kulturowo. Cechy dziedziczone są względnie stałe, a proces dziedziczenia jest jednokierunkowy oraz podlega zasadzie chronologii, co oznacza, że młodsze osobniki dziedziczą od starszych7. Jak pisze Ossowski: „na dziedzictwo kulturowe grupy społecznej składałyby się pewne wzory reakcji mięśniowych, uczuciowych i umysłowych, według których kształcą się dyspozycje członków grupy, ale żadne przedmioty zewnętrzne nie wchodziłyby w skład tego dziedzictwa"8. Zdaniem socjologa obejmowanie równorzędnym zakresem właściwości człowieka i przedmiotów jest niewskazane 9 , dlatego badacz wprowadza pojęcie „dorobku kulturalnego grupy społecznej"10. Autor przywoływanej koncepcji zaznacza, że dziedzictwo obejmuje to zagadnienie niezależnie od tego, skąd wzięły się przekazane wzory oraz w jaki sposób powstały konkretne przedmioty, czy zostały wytworzone przez człowieka z danej społeczności, czy zostały przyjęte z zewnątrz ${ }^{11}$. Zatem dziedzictwo kulturowe będą stanowiły również przedmioty przejęte $\mathrm{z}$ innych kultur oraz elementy przyrody ważne dla konkretnej grupy społecznej. Według badacza dziedzictwem kulturowym określimy obiekty, które są: „przedmiotem specyficznych przeżyć doznawanych dzięki posiadanym przez nas skomplikowanym dyspozycjom, które odziedziczyliśmy po innych przodkach swojej grupy i które prawdopodobnie przekażemy z takimi czy innymi zmianami swoim następcom"12.

Istotą dziedzictwa kulturowego są sposoby reagowania na określone przedmioty, elementy, wobec których żywi się pewne uczucia, a których źródłem są dyspozycje przekazane przez naszych przodków. Owa specyficzna postawa, która pozwala nam tak, a nie inaczej reagować

6 S. Ossowski, Więź społeczna i dziedzictwo krwi. Dzieła, t. 2, Warszawa 1966, s. 59.

7 Tamże, s. 60.

8 Tamże, s. 64.

9 Tamże, s. 64-65.

10 Tamże, s. 65.

11 Tamże.

12 Tamże. 
na konkretny przedmiot, to przypisanie mu niezwykłej wartości, dzięki której „przeszłość staje się dziedzictwem [...]”13. Autor pracy $Z z a-$ gadnień psychologii społecznej pisze, że pojęcie wartości można rozumieć w wąskim lub szerokim znaczeniu. W szerokim znaczeniu mamy do czynienia z wartościami dodatnimi, czyli tymi, których oczekujemy, i wartościami ujemnymi, których chcemy unikać ${ }^{14}$. Ze względu na kategorię przekonań zostały wyróżnione dwa rodzaje wartości: wartości odczuwane, gdy przedmiot jest pożądany, oraz wartości uznawane, które podlegają kontroli społecznej ${ }^{15}$. Taki podział prowadzi do powstania trzech kategorii. Według pierwszej mamy do czynienia z przedmiotami, które uznajemy za wartościowe i w taki sam sposób je odczuwamy. Druga sytuacja ma miejsce wówczas, gdy przedmioty są uznawane przez społeczeństwo, natomiast my nie uznajemy ich wartości. Trzecia sytuacja następuje, gdy dany przedmiot odczuwamy jako wartościowy, ale nie uznajemy go ${ }^{16}$. W ten sposób dziedzictwo kulturowe danej grupy tworzą elementy, którym dana społeczność przypisuje wartość lub nie przypisuje takiej wartości, a nawet przypisuje wartość ujemną. Elementy dziedzictwa, którym przypisuje się wartość ujemną, są przenoszone z pokolenia na pokolenie ${ }^{17}$.

Kolejnym elementem charakteryzującym dziedzictwo jest jego ciągłe podleganie zmianie $\mathrm{w}$ każdym pokoleniu ${ }^{18}$. W podobny sposób o dziedzictwie wyraża się Gregory J. Ashworth, który pisze, że dziedzictwo jest procesem, a nie typem zasobów ${ }^{19}$, w innej pracy ten sam autor zwraca uwagę, że dziedzictwo wynika ze współczesnych potrzeb i upodobań ${ }^{20}$.

Stanisław Ossowski w dalszej części swojej pracy podaje kolejne elementy dziedzictwa, mianowicie może ono być świadome lub nieświa-

13 K. Kowalski, O istocie dziedzictwa europejskiego, Kraków 2013, s. 5.

14 S. Ossowski, Z zagadnień psychologii społecznej, dz. cyt., s. 71.

15 Tamże, s. 73.

16 Tamże, s. 74.

17 S. Ossowski, Więź społeczna i dziedzictwo krwi, dz. cyt., s. 82.

18 Tamże, s. 237.

19 G.J. Ashworth, Sfragmentaryzowane dziedzictwo: sfragmentaryzowany instrument sfragmentaryzowanej polityki, w: Dziedzictwo kulturowe w XXI wieku, szanse i wyzwania, red. M. Murzyn, J. Purchała, Kraków 2007, s. 32-33.

20 G.J. Ashworth, Planowanie dziedzictwa, Kraków 2015, s. 32. 
dome. Dziedzictwo świadome może być chciane lub niechciane ${ }^{21}$. Świadomość i wola dziedziczenia wpływają na sposób transferu dziedzictwa oraz jego znaczenie w życiu jednostki. W tym miejscu należy przywołać postawę własności grupowej, wraz z poczuciem obowiązku wobec własnej społeczności ${ }^{22}$.

Szerokiej analizy koncepcji Stanisława Ossowskiego w swoich pracach dokonuje Piotr Petrykowski. Polski pedagog rozważa, jakie elementy wchodzą w obszar dziedzictwa kulturowego. Według Petrykowskiego przedstawione przez Stanisława Ossowskiego ujęcie dziedzictwa kulturowego pozwala włączyć w jego obszar elementy i wytwory, które kojarzą nam się pozytywnie, jednak przez inną grupę mogą być postrzegane jako negatywne, dlatego są odrzucane ${ }^{23}$. Pedagog zaznacza, że na wartość, jaką przypisujemy konkretnemu dziedzictwa, wpływa różnica pokoleń. Współcześni młodzi ludzie nie mają: „,W swoim bagażu doświadczeń walki o byt narodowy, tożsamość narodową i niepodległość, tak jak jest to udziałem pokoleń dorosłych: rodziców i ich rodziców. Kryteria uznawania wielu wytworów za składowe dziedzictwa kulturowego ulegają i ulegać muszą ciągłym zmianom, włączając weń i te elementy, które są pokoleniu dorosłych obce lub nie są przez nich akceptowane" 24 .

Z kolei Yi-Fu Tuan wskazuje, że „zdarza się często, że przedmiotów, które wywołują szacunek jednej grupy ludzkiej, druga w ogóle nie zauważa. Na percepcję wpływ wywiera kultura"25. Jak zatem widzimy, wartość dziedzictwa kulturowego zależna jest od wewnętrznych odczuć, zróżnicowania wewnątrzgrupowego oraz międzygrupowego.

Interesującym mnie obszarem jest magia rozumiana jako cecha dziedzictwa kulturowego. Zgodnie z przyjętą definicją przykłady wróżb i praktyk magicznych stanowią korelaty dziedzictwa kulturowego, które zostało ograniczone do wzorów reakcji mięśniowych, uczuciowych

21 S. Ossowski, Więź społeczna i dziedzictwo krwi, dz. cyt., s. 81.

22 Tamże.

23 P. Petrykowski, Dziedzictwo kulturowe a miejsce i czas, „Studia Edukacyjne”, 2013 nr 28, s. 96.

24 P. Petrykowski, Edukacyjne konteksty regionalizmu - stowarzyszenia społeczne, Toruń 2004, s. 235.

25 Yi-Fu Tuan, Przestrzeń i miejsce, Warszawa 1987, s. 206. 
i umysłowych, czyli specyficznych przeżyć, z jakimi wiążą się korelaty. Przeżycia te wynikają $\mathrm{z}$ dyspozycji, jakie dziedziczymy po naszych przodkach. W przypadku magii mamy do czynienia z dyspozycjami wrodzonymi i nabytymi. Jako dyspozycję wrodzoną traktuję myślenie magiczne, które jest całkowicie naturalnym procesem poznawczym występującym u dzieci i dorosłych. Dyspozycjami nabytymi są postawy, które w drodze naśladownictwa przejęliśmy od innych członków grupy ${ }^{26}$.

Magia stanowi ważki obszar dziedzictwa, jest bowiem ciągle obecna w kulturze, chociażby w postaci magii ludowej. Kościół, na ogół przeciwny obecności magii w życiu wiernych, dopuszcza pewne odstępstwa. Stanisław Bylina zwraca uwagę na magię schrystianizowaną, z którą mamy do czynienia w religijności ludowej ${ }^{27}$. Elementy, które wykorzystujemy w czasie świąt kościelnych, np. woda święcona, świece gromniczne, palemki wielkanocne czy kwiaty, stanowią rekwizyt ludowej dewocji. Według Ryszarda Tomickiego szczególnie wśród społeczności chłopskich elementy religijne i magiczne współwystępują, a nawet są jednym i drugim, w ten sposób modlitwa może być formułą magiczną i odwrotnie ${ }^{28}$. Należy pamiętać, że współcześnie przedstawiona magia ludowa nie odnosi się tylko i wyłącznie do tradycji z obszarów wiejskich. Według Ursa Altermatta słowo lud oznacza przeciętny, zwykły, co można odnieść do ogółu społeczeństwa, bez podziału na wieś i miasto $^{29}$. Poprzez religijność ludową i tradycje z nią związane praktyki magiczne obecne są w myśleniu i postępowaniu współczesnych ludzi.

\section{Badanie przekonań magicznych: uwagi metodologiczne}

Inspiracją do podjęcia tych badań była obserwacja przekonań magicznych ciągle obecnych w życiu codziennym oraz koncepcja dziedzictwa zaproponowana przez Stanisława Ossowskiego. Autor w jednym aka-

26 S. Ossowski, Więź społeczna i dziedzictwo krwi, dz. cyt., s. 38.

27 S. Bylina, Magia, czary i kultura ludowa w Polsce XV i XVI w., „Odrodzenie i Reformacja w Polsce", 1990 t. 35, s. 39-52.

28 R. Tomicki, Magia i mitologia $w$ kulturze ludowej (rozważania preliminarne), „Rocznik Muzeum Etnograficznego w Krakowie”, 1983 t. 8, s. 13.

29 U. Altermatt, Katolicyzm a nowoczesny świat, Kraków 1995, s. 98. 
picie swojej pracy pokazuje różnice pomiędzy magią ujmowaną jako część dziedzictwa kulturowego pojawiającą się u ludów pierwotnych i w cywilizacji zachodniej. Ten krótki fragment stanowił inspirację teoretyczną badań.

Celem badania było opisanie, poznanie i zrozumienie znaczenia przekonań magicznych obecnych w międzypokoleniowym przekazie dziedzictwa kulturowego. Główny problem badawczy został wyrażony w następującym pytaniu: Jakie znaczenie dla współczesnych rodzin mają przekonania magiczne obecne w międzypokoleniowym przekazie dziedzictwa kulturowego?

W badaniu zastosowano strategię jakościową, wyjaśnienie idiograficzne i schemat etnograficzny. Należy za Krzysztofem Rubachą zaznaczyć, że: „badania jakościowe, których rezultatem są analizy wykonywane na danych w postaci tekstu, służą formułowaniu prawidłowości odnoszonych do jednostkowych miejsc, indywidualnych doświadczeń edukacyjnych poszczególnych osób" ${ }^{30}$. Przyjęta strategia pozwala na zrozumienie interesującego mnie zjawiska poprzez odtworzenie wewnętrznej perspektywy osób uczestniczących w badaniu. Badanie prowadzone było według schematu etnograficznego, a wywiady etnograficzne, częściowo ustrukturalizowane, umożliwiły uzyskanie odpowiedzi na postawione pytania oraz dodatkowo pozwoliły na swobodną wypowiedź moim informatorom, dzięki czemu możliwe było zdobycie informacji, które były ważne również dla nich. Metoda etnograficzna została opracowana do badania niewielkich społeczności, a z czasem i enklaw rasowych, etnicznych czy wiekowych ${ }^{31}$, dlatego została uznana za odpowiednią.

Badanie zostało przeprowadzone na terenie miasta Turek, uczestniczyło w nim 6 rodzin, łącznie 21 osób. Ważnym elementem jest fakt, że było ono prowadzone na obszarze miasta, z którego pochodzę. Wybranie terenu badań znanego badaczowi rodzi pewne pytania i wątpliwości. Według Jamesa Clifforda teren badań nie musi być tylko obszarem odległym dla badacza, może być to okolica lub budynek, w którym

${ }^{30}$ K. Rubacha, Metodologia badań nad edukacja, Warszawa 2008, s. 20.

31 M. Angrosino, Badania etnograficzne i obserwacyjne, Warszawa 2010, s. 52. 
mieszkamy ${ }^{32}$. Na ten temat pisze również R. Firth: „Skoro możemy się problemami antropologicznymi zajmować gdziekolwiek, to równie dobrze możemy udać się tam, gdzie będzie nam wygodnie"33. Prowadząc anthropology at home, stykamy się z licznymi ułatwieniami i paradoksalnie wynikającymi z nich trudnościami. Przede wszystkim nie trzeba wnikać w obszar obcy, nie jest się wizytującym cudzoziemcem ${ }^{34}$, z drugiej strony istnieje ryzyko pominięcia, niezauważenia lub zlekceważenia wielu cennych rzeczy ${ }^{35}$. W tym miejscu należy wskazać na rozważania Kirin Narayan ${ }^{36}$, która przedstawiła wielorakie tożsamości badacza, niepozwalające na usytuowanie go na pozycji przedstawiciela konkretnej społeczności. W trakcie opuszczenia murów uczelni i wejścia w teren badacz jest badaczem, należy do innej społeczności niż jego rozmówcy. Ważne jest zachowanie wrażliwości etnograficznej, etnograf-pedagog cały czas powinien pielęgnować w sobie nastawienie antropologiczne, czyli otwartość i postawę naiwno-poznawczą.

Dobór osób badanych miał charakter celowy - w badaniu uczestniczyły rodziny zamieszkałe na terenie miasta Turek i mające dzieci. Do osób uczestniczących w badaniu docierałam poprzez kontakty nieformalne, często były to osoby, które zgłosiły się do mnie, a o tym, że prowadzę badanie, dowiedziały się od znajomych. Część rodzin pozyskałam metodą kuli śniegowej, a część sama zaprosiłam do badania. Łącznie w badaniu uczestniczyło 6 rodzin - 21 osób, w tym 6 dzieci.

32 J. Clifford, Praktyki przestrzenne: badania terenowe, podróże i praktyki dyscyplinujace $w$ teorii, w: Badania kultury. Elementy teorii antropologicznej, kontynuacje, red. M. Kempy, E. Nowicka, Warszawa 2004, s. 145.

33 Cyt. za: T.H. Eriksen, Małe miejsca, wielkie sprawy. Wprowadzenie do antropologii społecznej i kulturowej, tłum. J. Wołyńska, Warszawa 2009, s. 41.

34 T. Rakowski, Antropolog jako wizytator nędzy. Rozważania o kulturze niemocy, „Kultura i Społeczeństwo”, 2002 nr 4, s. 67.

35 T.H. Eriksen, Małe miejsca wielkie sprawy. Wprowadzenie do antropologii społecznej i kulturowej, dz. cyt., s. 41.

${ }^{36} \mathrm{~K}$. Narayan, How native is a "native” anthropologist?, „American Anthropologist", 1995 No. 95(3), s. 24. 


\section{Praktyczna typologia magii: rekonstrukcja na podstawie badań empirycznych}

Na podstawie przeprowadzonych rozmów możliwe było stworzenie typologii magii. Zebrany materiał pozwolił na wyszczególnienie następujących kategorii magii: epitet, iluzja, wiedza prelogiczna, opozycja do religii, coś niesamowitego bądź niewytłumaczalnego. W większości przypadków pierwszym skojarzeniem, jakie przychodziło do głowy moim rozmówcom, było skojarzenie magii z przenośnią, co obrazują poniższe przykłady:

KSI: No tak jak, no to tak szczęśliwie, no, bo tak... jest dzień magicznym dniem.

KAII: Może zacznę od dziadków. Mhm... Dla mnie u nich magiczne było to, że po prostu się bardzo kochali. Naprawdę bardzo. Bo byli bardzo zgranym małżeństwem.

W tym przypadku magia jest epitetem, który podkreśla wyjątkowość jakichś zdarzeń oraz momentów życiowych. Powyższy sposób rozumienia magii odpowiada jego słownikowym objaśnieniom, które znajdziemy w Słowniku języka polskiego ${ }^{37}$ czy w Praktycznym słowniku wspótczesnej polszczyzny ${ }^{38}$.

Dość wyraźną kategorią wśród rozmówców, a szczególnie wśród najmłodszych, jest określanie magii jako iluzji, rozrywki przeznaczonej dla dzieci:

KSII: A magia - no to, no różnie. Jakieś występy, magia, takie rzeczy, coś takiego, tak?

KKI: magik, który wyciąga królika z kapelusza.

KBII: czary mary dla dzieci

MB3I: sztuczki bawiące

37 Słownik języka polskiego, t. 4, red. W. Doroszewski, Warszawa 1963, s. 366.

38 Praktyczny słownik wspótczesnej polszczyzny, t. 20, red. H. Zgółkowa, Poznań 1999, s. 96. 
W podanych definicjach uwagę zwraca użycie słowa sztuka, co wskazuje ukierunkowanie na pewną formę artystyczną, sztukę iluzjonistyczną, służącą rozrywce.

Magia jako forma wiedzy prelogicznej pojawia się w wypowiedziach dwóch mężczyzn. Definicje przez nich podane nacechowane są terminologią podręcznikową o charakterze naukowym: MBII: „magia to zespół gestów i rytuałów, które mają zmienić rzeczywistość". Mój rozmówca podkreślił również, że wiara w magię jest wynikiem dwóch czynników, pierwszy odniósł do kwestii niedouczenia i braku wiedzy, które były charakterystyczne dla ludzi żyjących w dawnych czasach. Za drugi czynnik odpowiadający za obecność magii w życiu ludzi rozmówca uznał ciągle niedostateczną wiedzę na temat pewnych zjawisk, „margines niezbadany przez naukę".

W kolejnej kategorii magia uważana jest za coś rzeczywistego, znajdującego się w opozycji do religii:

KSIII: To się zmieniło, bo więcej, wiesz, wierzę. I to mnie przekonuje. Wierzę po prostu w Boga więcej. I to mnie przekonuje, że magia nie jest dobrym celem. No tak mi się wydaje.

Jedną z częściej przytaczanych definicji było uznanie magii za coś niezrozumiałego, czego przykładem są stwierdzenia:

MZII: czymś niestworzonym. Czymś, nie wiem, wyjątkowym. [...] coś nie $\mathrm{z}$ tej ziemi.

KCII: Magia? No to coś, czego nie da się wytłumaczyć. No i to tyle.

KA: Nie wiem. Czymś takim magicznym. Czymś takim nie z naszego świata.

Taki sposób definiowania magii odpowiada sposobowi, w jaki magię określa Anna Engelking 39 .

W wypowiedziach rozmówców samo słowo magia padało rzadko, w dalszej części wywiadów uciekali od niego i stosowali zamiennie terminy: czary, zabobon, przesąd. To zjawisko wyjaśnia Anna Engelking. Badaczka wskazuje, że „słowiańska kultura ludowa nie wyróżniła lek-

39 A. Engelking, Klątwa, rzecz o ludowej magii słowa, Wrocław 2000, s. 20. 
sykalnie żadnej nadrzędnej, ogólnej kategorii magii, że nie zna słowa magia"40. Magia jest określeniem stosowanym przez badaczy i występuje w ich odautorskich tekstach. Tym samym słowo magia nie stanowi językowego obrazu świata kultury ludowej, w której mamy od czynienia z zamawianiem i odczynianiem ${ }^{41}$. Stąd też dla osób uczestniczących w badaniu bardziej odpowiednim terminem jest czar ${ }^{42}$, czyli słowo wspólne dla wszystkich Słowian, oznaczające „praktyki magiczne wykonywane na szkodę bliźnich"ł3.

Kolejnym szczególnie ważnym wątkiem jest ten dotyczący treści, których rozmówcy nie postrzegają jako magiczne. W tej kategorii można umieścić wszelkie elementy szeroko pojmowanej religijności ludowej. Dawne praktyki utraciły pierwiastek magiczny na rzecz obrzędowości chrześcijańskiej, a wręcz zostały ulokowane w obszarze „tradycji wielkich" ${ }^{\prime 4}$, których przekaz ma zazwyczaj charakter świadomy i często zinstytucjonalizowany.

Inaczej wygląda sytuacja w przypadku „tradycji małych”, czyli przesądów, zabobonów i praktyk stosowanych w domach, ich przekaz jest zazwyczaj nieświadomy.

Kolejny podział dotyczył magii żywej i pamiętanej. Magia żywa, ciągle praktykowana, to przede wszystkim zwyczaje należące do grupy „tradycji wielkich”, związane z uroczystościami i celebracjami świąt, ale również przesądy i wierzenia zaliczane do „tradycji małych”, jak czarny kot, czterolistna koniczyna, zbite lustro, oraz praktyki magiczne o charakterze profilaktycznym i leczniczym: czerwona wstążka w wózku dziecka, przelewanie wosku nad główką dziecka. Są to również zwyczaje, które wiążą się z silnymi emocjami czy postawą poczucia własności i doniosłości pewnych zdarzeń, przykładem może być lęk przed przekroczeniem czy postawa wobec świąt religijnych. Elementy

40 Tamże, s. 28.

41 Tamże, s. 23-29.

42 Z. Grębecka zaznacza, że w przypadku magii z wyboru, czyli u osób, które świadomie przyjęły taką postawę życiową, pojawiają się określenia magia oraz magia ludowa. Z. Grębecka, Stowo magiczne poddane technologii. Magia ludowa w praktykach postsowieckiej kultury popularnej, Kraków 2006, s. 21.

43 K. Moszyński, Kultura ludowa Słowian, t. 2, cz. 1, Warszawa 1968, s. 343.

44 J. Szacki, Tradycja, Warszawa 2011, s. 113. 
i czynności magiczne, które należą do tradycji pamiętanej, to opowieści rodzinne przekazywane z pokolenia na pokolenie. Zawierają przykłady praktyk magicznych, jednak stanowią tylko element pewnych historii i nie są praktykowane przez współczesne rodziny.

\section{Wobec praktyk magicznych: postawy osób uczestniczących w badaniu}

Zgodnie ze sposobami definiowania magii można wskazać na następujące postawy moich rozmówców wobec praktyk magicznych. Do pierwszej grupy należą osoby, które określają siebie jako niewierzące w przejawy magiczne. W drugiej grupie, którą określiłam za Dorotą Simonides jako Halfbelieff5, są osoby najczęściej uznające się za nieprzesądne, jednak w pewnych sytuacjach stosujące się do reguł magicznych. Ostatnią grupę tworzą osoby przesądne. Rozmówcy, którzy deklarują niewiarę w magię, uzasadniają swoją postawę poprzez sposób pojmowania magii jako prenauki, ciemnoty i oszustwa. Co ciekawe, w tej grupie znalazły się również dzieci, które magię postrzegają głównie jako sztuczki iluzjonisty, w rzeczywistości będące tylko oszukiwaniem.

Osoby zaliczone przeze mnie do grupy drugiej, które określiłam jako Halfbelief, najlepiej charakteryzuje wypowiedź mojej rozmówczyni:

KKII: To jest takie no... No jakby było obojętne, to by może człowiek tego nie robił, no nie? A że robi, to chyba musi być nieobojętne, no nie?

Przyjęłam, że w grupie Halfbelief znajdą się osoby zarówno motywowane zewnętrznie, jak i motywowane wewnętrznie wobec wierzeń i praktyk magicznych:

KKII: - Nie, obojętne to nie jest. To jest takie no... No jakby było obojętne, to by może człowiek tego nie robił, no nie? A że robi, to chyba musi być nieobojętne, no nie? Także no chyba to nie jest obojętne, że, że, jak to się mówi, że się człowiek stosuje do tego. Może można powiedzieć, że nie

45 D. Simonides, Współczesny folklor słowny dzieci i nastolatków, Wrocław 1974, s. 192 . 
wierzę. No nie wiem. Nie. Teraz może źle mówię, że nie wierzę, bo jeżeli to stosuję, to, no to jakąś tam. Musi do tego, musi w to wierzyć, że tak robi, no nie? Może wierzyć, no wierzyć w sensie takim, że no, yyy, zapomniałam czegoś, wracam się i usiądę, żeby, żeby naprawdę mi się coś tam nie stało, no nie? Bo jak na przykład...

- Jednak jest taka wiara?

- No wiara, wiara, no wiara to jest w Boga, tak? Wierzy się, człowiek wierzy w Boga. A to jest bardziej takie no, takie no zrobię to, żeby, żeby coś się nie stało.

- Przezorność?

- Przezorność. O! Brakło mi słowa. Dokładnie.

KAII: Mi się wydaje, że lepiej na zimne dmuchać. Gdyby się miało coś stać. Chyba z tego względu bardziej. Ale nie jestem do końca tego przekonana.

W trzeciej grupie znalazły się osoby przesądne, które przestrzegają przesądów:

MSII: - No lepiej być przezornym.

- Poważnie?

- No tak.

- Znaczy nie no... Czy wierzyć? No jeże... Nosz ten na przykład, że jak kot przebiegł, no to tak już jest, no to lege... znaczy. No nigdy nie słyszałem, żeby akurat ktoś mi tam powiedział, że „O, stało się coś, bo mi akurat kot przebiegł przez drogę”. No tak mi tak jeszcze tak nikt nie powiedział, nie? No, ale, no u nas tak przestrzegają to wszyscy i... No przestrzegają, no mówią, żeby tak nie robić. No to, no tak się nie robi. I co tam?

Rozmówcy wiarę w przesądy motywują na dwa sposoby. Przede wszystkim kierują się poczuciem lęku przed zdarzeniami przykrymi oraz postępują $\mathrm{w}$ taki sposób, w jaki postępowała i postępuje ich rodzina.

$\mathrm{Z}$ analizy wynika, że praktyki magiczne, jako część dziedzictwa kulturowego, są płynne i potencjalne. Szczególnie wybrzmiewa to wśród osób starszych, które zaznaczają, że wraz z wiekiem stają się coraz mniej przesądne. W ciągu życia zmianie ulega również repertuar przesądów, inne zabobony przeważają u dzieci, inne u rodziców, a inne u osób starszych. Różnorodność ta jest związana z etapami życia tych osób oraz trudnościami w życiu, z jakimi muszą się mierzyć. Wśród dzieci są to 
najczęściej zabobony związane ze szkołą, takie jak przydeptywanie upuszczonego zeszytu, przedmiot przynoszący szczęście, u osób dorosłych, którzy mają dzieci, zazwyczaj są to zabobony związane z ochroną dziecka i jego bezpieczeństwem oraz z bezpieczeństwem ogólnie. U starszych osób miejsce zabobonności zajmuje wiara i oddanie się pod opiekę Boga.

Potencjalność obejmuje również zwyczaje obce, które przeniknęły do naszej kultury i traktowane są jako własne. Do takich moi rozmówcy zaliczają Walentynki, Dzień Kobiet czy negatywnie oceniane Halloween. Wśród postaci magicznych prym wiodą te związane z przemysłem filmowym - rodzime ogniki, strzygi czy południce zastąpiły bajkowe jednorożce czy serialowe wampiry. Magia jako dziedzictwo kulturowe nie jest spetryfikowaną przeszłością, podlega ciągłym przeobrażeniom, nie tylko tym związanym z wyżej opisanymi etapami życia, ale również tym zależnym od zmian kulturowych. Wśród mechanizmów selekcji dziedzictwa kulturowego należy wymienić, obok opisanej już potencjalności, wartość.

Nadanie wartości elementowi z przeszłości stanowi najważniejszy mechanizm selekcji dziedzictwa kulturowego. Magię badani waloryzują pozytywnie lub negatywnie, określając ją jako niepotrzebną, nieracjonalną, przeżytek, bzdurę. Wartości, jakie rozmówcy przypisywali badanemu dziedzictwu, to wartość użytkowa, psychologiczna, społeczna, emocjonalna, duchowa, historyczna i edukacyjna. Oscylują one wokół głównych motywacji podjęcia praktyk magicznych, do których należy lęk, nostalgia, afirmacja przeszłości. W przypadku nostalgii oraz afirmacji przeszłości przekonania magiczne są ciągle żywe, ponieważ stanowią dziedzictwo po naszych przodkach. Spadek ten ma dwojaki charakter jest spuścizną kulturową oraz psychologiczną. Według Doroty Simonides tradycyjny przekaz magiczny jest przez nas bezrefleksyjnie przyjmowany, ponieważ legitymizuje go autorytet poprzednich pokoleńt ${ }^{4}$ w myśl zasady „tak zawsze było”47. Obok autorytetu przeszłych pokoleń

46 S. Simonides, Mądrość ludowa. Dziedzictwo kulturowe Śląska Opolskiego, Wrocław 2007.

47 E. Shills, Tradycja, w: Tradycja i nowoczesność, red. J. Kurczewska, J. Szacki, Warszawa 1984, s. 55. 
mamy do czynienia z nostalgicznym patrzeniem w przeszłość, które David Lowenthal określa jako idealizacyjne wspomnienie, dużo lepsze, niż było w rzeczywistości ${ }^{48}$. Cenimy coś dlatego, że po prostu było ${ }^{49}$.

U osób dorosłych myślenie magiczne jest mechanizmem obrony, którego źródło znajduje się w pozostałościach dziecięcego myślenia. Dowodem tego są liczne wróżby i wierzenia, które skupiają się na szeroko pojętym dobrostanie. Celem procesów magicznych jest złagodzenie lęku, który Antoni Kępiński określa jako negatywne uczucie, o ujemnym znaku, które wiąże się z postawą ucieczki i skupia na przeżyciu. Wprowadzając porządek w swój świat, człowiek oswaja lęk. To właśnie z lęku rodzą się demony i bóstwa, przed którymi odczuwamy strach, a czasem darzymy je szacunkiem i miłością. W ten sposób myślenie magiczne stanowi mechanizm adaptacyjny umożliwiający przetrwanie ${ }^{50}$. Dzieje się tak niezależnie od tego, czy żyjemy w świecie racjonalnym, czy w świecie naznaczonym mitologią i myśleniem magicznym. Gustav Jahoda podkreśla, że przesądy nie są aberracjami, ale pojawiają się jako wskaźnik społecznych konfliktów i napięć oraz sposób redukowania wrogości i naprawy więzi społecznych ${ }^{51}$. Dlatego możemy pokusić się o stwierdzenie, że pozycja magii we współczesnym społeczeństwie jest niezagrożona ze względu na rolę, jaką pełni, ale również na wartość, jaką jej przypisujemy, gdy określamy ją jako cechę naszego dziedzictwa kulturowego, spuściznę naszych przodków.

\section{Przekonania magiczne jako to, co dziedziczone}

Kolejnym zagadnieniem poruszanym $\mathrm{w}$ badaniu jest proces dziedziczenia przekonań magicznych. Analiza wypowiedzi rozmówców pozwoliła na wskazanie trzech głównych źródeł praktyk i wierzeń magicznych, do których należą: krąg rodzinny, rówieśnicy i popkultura, mass media. Tylko jedna dziewczynka wskazała na podręcznik szkolny i lekcję poświęconą przesądom. W zakresie wyboru osób, od których decydujemy

\footnotetext{
48 D. Lowenthal, The Past is a Foreign Country, Cambridge 2015, s. 40.

49 E. Shills, Tradycja, dz. cyt., s. 55.

50 G. Jahoda, Psychologia przesądu, Warszawa 1971, s. 214.

51 Tamże, s. 144.
} 
się dziedziczyć, na przestrzeni pokoleń zaszły spore zmiany. Obecnie starsze kobiety, we wspomnieniach swojego dzieciństwa, jako główne źródło wymieniają rodzinę, przede wszystkim kobiety (mamy, babcie, ciocie, teściowe), oraz krąg rówieśniczy. Respondenci, pytani o bohaterów i historie związane $\mathrm{z}$ magią, wspominają postacie występujące w opowieściach ich bliskich, które są charakterystyczne dla kultury ludowej. Wśród przykładów znajdziemy bagienne ogniki, czarta, diabły czy uroczne oczy. Współczesne dzieci jako główne źródło informacji na temat przesądów wskazują rówieśników, rodziców i kulturę popularną. Zapytane o postacie magiczne, wymieniają bohaterów bajek, filmów i seriali. Dla wszystkich pokoleń charakterystyczne jest znaczenie kręgu rówieśniczego, który w latach szkolnych ma duży wpływ na dzieci. W tym czasie przeważają przesądy związane $\mathrm{z}$ folklorem dziecięcym.

Proces transmisji przekonań magicznych w obrębie rodziny często ma charakter nieświadomy, nieintencjonalny, występuje jako ustne pouczenie i modelowanie. Przekazowi nieświadomemu podlegają zachowania, schematy, dyspozycje emocjonalne, które odpowiadają za określone reagowanie na elementy kultury. Osoby, z którymi przeprowadzałam wywiady, przeważnie nieświadomie przejmują zachowania i schematy myślenia w oparciu o postawę własności grupowej i poczucie obowiązku. Nie potrafią wyjaśnić, dlaczego w konkretnych sytuacjach zachowują się w określony sposób, nie znają przyczyn stosowania pewnych gestów czy słów, a nawet często nie są pewni efektów, jakie może przynieść zaniechanie lub wykonanie konkretnego gestu. Zatem w przeważającej większości mamy do czynienia z postępowaniem nieświadomym. Z kolei przekaz świadomy, który zauważyłam u mniej licznej grupy rozmówców, ma dwa wymiary. Pierwszy dotyczy zwyczajów związanych z uroczystościami religijnymi. Artefakty czy zwyczaje magiczne połączone z obchodami religijnymi zatracają swój magiczny charakter. Przykładem jest reguła pozostawiania pustego miejsca przy stole. Zwyczaj ten zatracił swój magiczny charakter, współcześnie oczekiwanie na zagubionego przybysza jest zwyczajem świadomym i chcianym. Drugi wymiar dotyczy praktyk i wierzeń magicznych, które traktowane są jako element historii, ciekawostka z dawnych dziejów, w której moc się nie wierzy. Ciekawostka jest znakiem czasów, które minęły, a które według moich rozmówców warte są 
zapamiętania i przekazania kolejnym pokoleniom, ponieważ stanowią element naszej kultury, podobnie jak pamięć o stoczonych walkach, strojach ludowych czy legendach.

\section{Zakończenie}

Celem badań było przedstawienie znaczenia przekonań magicznych obecnych w międzypokoleniowym przekazie dziedzictwa kulturowego. W świetle zgromadzonego materiału możliwe było skonstruowanie typologii magii. Badania pozwoliły na wyszczególnienie następujących kategorii, w których magia traktowana jest jako epitet, iluzja, wiedza prelogiczna, opozycja do religii, coś niesamowitego bądź niewytłumaczalnego. Kolejnym interesującym wątkiem jest ten pozwalający na umieszczenie praktyk magicznych w kategoriach tradycji wielkich, do których należą elementy religijności ludowej, oraz tradycji małych, które tworzą codzienne przesądy. Z przedstawionym podziałem wiąże się również podział na magię żywą i pamiętaną.

Kolejny wątek badań pozwolił wyszczególnić trzy postawy wobec magii. Osoby biorące udział w badaniu można zaklasyfikować do trzech grup: osoby niewierzące, Halfbelief oraz osoby wierzące. Wśród motywacji dotyczących wiary w przesądy można wyróżnić poczucie lęku przed przyszłymi nieprzyjemnymi zdarzeniami oraz chęć postępowania zgodnie $\mathrm{z}$ tradycją.

Analiza zebranego materiału pod kątem dziedzictwa kulturowego pozwoliła określić opisywane dziedzictwo jako płynne i potencjalne. Mozaika przesądów ulega zmianie w ciągu życia zgodnie z zegarem biologicznym człowieka i dzięki nowym elementom przenikającym z innych kultur. Dziedzictwo wyróżnia również nadanie wartości elementowi z przeszłości. Rozmówcy przypisywali magii wartości ujemne i dodatnie.

Analizując proces dziedziczenia przekonań magicznych, można wskazać na trzy główne źródła praktyk i wierzeń magicznych: krąg rodzinny, krąg rówieśniczy oraz popkultura. Na przestrzeni pokoleń zmianie uległ również krąg, z którego dziedziczymy, współcześnie coraz większe znaczenie ma kultura popularna. Należy także wymienić 
dwa sposoby dziedziczenia przekonań magicznych: nieświadomy oraz świadomy i intencjonalny.

Znajomość własnego dziedzictwa, nie tylko tego lokalnego, ale również tradycji rodzinnych, jest ważna dla zachowania pamięci o przodkach, budowania poczucia wewnątrzrodzinnej wspólnoty i odrębności na tle innych rodzin. Dla większości badanych magia stanowi ważny element życia, jest obecna na każdym jego etapie, towarzyszy w ważnych momentach, mimo że często nie są oni tego świadomi. A świadomość własnego dziedzictwa jest istotnym elementem własnej tożsamości. Refleksję na temat dziedzictwa kulturowego można zamknąć w zdaniu, że nie ma „nas” bez dziedzictwa, podobnie jak nie ma dziedzictwa bez nas.

\section{Bibliografia}

Altermatt, Urs. Katolicyzm a nowoczesny świat, tłum. Grzegorz Sowiński. Kraków: ZNAK, Ośrodek Myśli Politycznej, 1995.

Angrosino, Michael. Badania etnograficzne i obserwacyjne, tłum. Maja Brzozowska-Brywczyńska. Warszawa: Wydawnictwo Naukowe PWN, 2010.

Ashworth, Gregory J. Planowanie dziedzictwa. Kraków: Międzynarodowe Centrum Kultury, 2015.

Ashworth, Gregory J. Sfragmentaryzowane dziedzictwo: sfragmentaryzowany instrument sfragmentaryzowanej polityki. W: Dziedzictwo kulturowe w XXI wieku, szanse i wyzwania, red. Monika A. Murzyn, Jacek Purchała, 29-42. Kraków: Międzynarodowe Centrum Kultury, 2007.

Bylina, Stanisław. „Magia, czary i kultura ludowa w Polsce XV i XVI w.” Odrodzenie i Reformacja w Polsce t. 35 (1990): 39-52.

Clifford, James. „Praktyki przestrzenne: badania terenowe, podróże i praktyki dyscyplinujące w teorii", tłum. Sławomir Sikora. W: Badania kultury. Elementy teorii antropologicznej, kontynuacje, wyb. Marian Kempy, Ewa Nowicka, 137-179. Warszawa: Wydawnictwo Naukowe PWN, 2004.

Engelking, Anna. Klątwa, rzecz o ludowej magii słowa. Wrocław: Oficyna Naukowa, 2000.

Eriksen, Thomas Hylland. Małe miejsca, wielkie sprawy. Wprowadzenie do antropologii społecznej i kulturowej, tłum. Joanna Wołyńska, Warszawa: Oficyna Wydawnicza Volumen 2009. 
Grębecka, Zuzanna. Stowo magiczne poddane technologii. Magia ludowa $w$ praktykach postsowieckiej kultury popularnej. Kraków: Zakład Wydawniczy Nomos, 2006.

Jahoda, Gustav. Psychologia przesq̨du, tłum. Jerzy Jedlicki. Warszawa: Państwowy Instytut Wydawniczy, 1971.

Kowalski, Krzysztof. O istocie dziedzictwa europejskiego. Rozważania. Kraków: Międzynarodowe Centrum Kultury, 2013.

Lowenthal, David. The Past is a Foreign Country. Cambridge: Cambridge University Press, 2015.

Malinowski, Bronisław. Mit, magia, religia, tłum. Barbara Leś, Dorota Praszałowicz. Warszawa: Państwowe Wydawnictwo Naukowe, 1990.

Moszyński, Kazimierz. Kultura ludowa Słowian, t. 2, cz. 1. Warszawa: Książka i Wiedza, 1968.

Mrozek-Dumanowska, Anna. Człowiek w labiryncie magii. Warszawa: Wiedza Powszechna, 1990.

Narayan, Kirin. „How native is a 'native' anthropologist?”. American Anthropologist No. 95(3) (1993): 671-686.

Ossowski, Stanisław. Więź społeczna i dziedzictwo krwi. Dzieła, t. 2. Warszawa: Państwowe Wydawnictwo Naukowe, 1966.

Ossowski, Stanisław. Z zagadnień psychologii społecznej. Dzieła, t. 3. Warszawa: Państwowe Wydawnictwo Naukowe, 1967.

Petrykowski, Piotr. „Dziedzictwo kulturowe a miejsce i czas”. Studia Edukacyjne nr 28 (2013): 93-107.

Petrykowski, Piotr. Edukacyjne konteksty regionalizmu - stowarzyszenia społeczne. Toruń: Zakład Usług Poligraficznych Gestor 2004.

Praktyczny słownik współczesnej polszczyzny, t. 20, red. Halina Zgółkowa. Poznań: Wydawnictwo „Kurpisz”, 1999.

Rakowski, Tomasz. „Antropolog jako wizytator nędzy. Rozważania o kulturze niemocy". Kultura i Społeczeństwo t. 46 nr 4 (2002): 67-79.

Rubacha, Krzysztof. Metodologia badań nad edukacją. Warszawa: Wydawnictwa Akademickie i Profesjonalne, 2008.

Schulz, Roman. „Pedagogika jako nauka o człowieku - próba dookreślenia idei". W: Pedagogika we wspótczesnym dyskursie humanistycznym, red. Tadeusz Lewowicki, 59-66. Warszawa-Kraków: Wyższa Szkoła Pedagogiczna, Oficyna Wydawnicza Impuls, 2004. 
Shills, Edward. „Tradycja”, tłum. Jerzy Szacki. W: Tradycja i nowoczesność, red. Joanna Kurczewska, Jerzy Szacki, 30-90. Warszawa: Wydawnictwo Czytelnik, 1984.

Simonides, Dorota. Mądrość ludowa. Dziedzictwo kulturowe Śląska Opolskiego. Wrocław: Polskie Towarzystwo Ludoznawcze, 2007.

Simonides, Dorota. Wspótczesny folklor słowny dzieci i nastolatków. Wrocław: Państwowe Wydawnictwo Naukowe, 1974.

Stownik języka polskiego, t. 4, red. Witold Doroszewski. Warszawa: Państwowe Wydawnictwo Naukowe, 1963.

Szacki, Jerzy. Tradycja. Warszawa: Wydawnictwo Uniwersytetu Warszawskiego, 2011.

Tomicki, Ryszard. „Magia i mitologia w kulturze ludowej (rozważania preliminarne)". Rocznik Muzeum Etnograficznego w Krakowie t. 8 (1983): 7-24.

Tuan, Yi-Fu. Przestrzeń i miejsce, tłum. Agnieszka Morawińska. Warszawa: Państwowy Instytut Wydawniczy, 1987. 